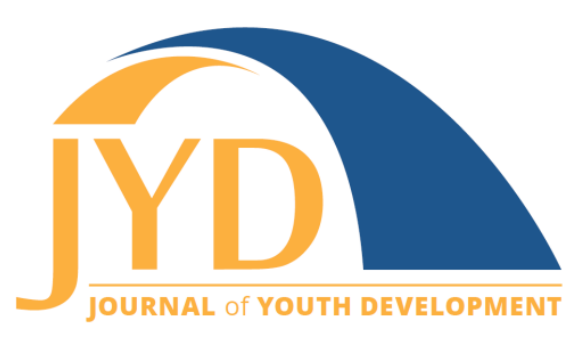

http://jyd. pitt. edu/ | Vol. 14 Issue 2 DOI 10.5195/jyd.2019.790 | ISSN 2325-4017 (online)

\title{
From Immigrant to American
}

\section{Hwanhui Seo}

\begin{abstract}
A language barrier can be especially challenging for immigrants to the United States as described by the native Korean youth author. It affects all aspects of one's life from school to everyday life experiences such as ordering in restaurants and requires time and commitment to overcome.
\end{abstract}

Key words: foreign language learning, immigrant youth responsibilities, determination

A change of environment is a very common occurrence. Simply moving my location changes what I look at, listen to, and feel. I had gone through changes hundreds of times in my life, such as when I entered my new school, or when I went to a sleepover at my friend's house. Whenever I experienced a new environment back then, they were just small events that I might write one or two sentences of in my diary.

To be honest, I don't keep my diary. Like most people, I buy a good-looking diary, fill it for two or three weeks, and I stop. But the day I moved to America, I needed a huge paper to write about the move. It was a historic and unforgettable day. I strongly felt that my second life was about to start when I got on the plane. Apparently, after I landed, I had to learn and change everything that I had learned from the time I was a toddler except for breathing. A change of cognition was required by the change of environment. Like a 3-year-old child, I had to ask people about every little thing. I was responsible for all the paperwork to be done because I was the least bad in English in my family. I had so many questions: How to rent an apartment? How to write a check? How to enroll in school? and How come a small drink in a fast food restaurant is as big as a large drink in a Korean one? I was too naïve to settle my family in a foreign country. I am finally doing well now-thanks to a lot of hard work but-still, I'm not fully adapted.

(cc) EY New articles in this journal are licensed under a Creative Commons Attribution 4.0 License. This journal is published by the University Library System, University of Pittsburgh and is cosponsored by the University of Pittsburgh Press. The Journal of Youth Development is the official peer-reviewed publication of the National Association of Extension 4-H Agents and the National AfterSchool Association. 
The toughest part of immigration is definitely the language. The Korean language doesn't share any root of language with English. Also, the Korean letters are not even similar to the Roman Alphabet; Korean has its own unique writing system. Even though I studied English before I came to America, I was able to communicate using only simple words. However, to catch up with the native English speakers in school, I had to work two to three times harder than them on account of the huge disadvantage. When I opened up a high school textbook randomly, I didn't know the majority of English words on the page. I still feel frustrated when I see those tens of unknown words that I should look for the definition of. What is worse, there are words that I don't know in the definition, too. After this infinite loop of finding definitions, I forget what it was. Then, I start over.

Whenever I feel sick and tired of English, I murmur lying on the bed: "What if I was born here? It takes time to be fluent in English-the process is time-consuming and too tough for me to go through." I am envious of people whose mother language is English. English is not the only language to know as one's first language; I am proud of being a native Korean speaker since there are numerous people who want to learn Korean owing to the significant influence of Korean culture around the world. However, while living in America, English is absolutely important to manage to survive. Indeed, I always think of the fastest way to master English. And the only way I can improve my English in my given environment is repeating over and over.

It has been 2 years and a half since I moved here. I used to complain about myself-why my English is not as good as American people's. I sometimes thought I am not smart enough to learn English. But the fact is the amount of time I have lived here is not enough to satisfy my expectation of myself. There is one thing I have proudly accomplished: I have accepted how hard and time-consuming it is to learn a new language. Learning a new language is not 2 to 3 sentences long in the diary; it is countless sentences long that wouldn't fit in 1-year diary. So I don't get frustrated anymore when I encounter hardship in understanding English. Instead, the harder it is, the more it inspires me to work harder on it. 